University of New England

DUNE: DigitalUNE

$12-2019$

Migration Tactics Of A Long-Distance Migratory Songbird From Across A Continental Breeding Range

Rosalind Renfrew

Dan Kim

Noah G. Perlut

Michael D. Cadman

Follow this and additional works at: https://dune.une.edu/env_facpubs

Part of the Ornithology Commons 


\title{
Migration tactics of a long-distance migratory songbird from across a continental breeding range
}

\author{
Rosalind Renfrew, ${ }^{1 *}$ Dan Kim, ${ }^{2}$ Noah Perlut, ${ }^{3}$ and Michael D. Cadman ${ }^{4}$
}

\begin{abstract}
Migration strategies in the avian world are often compared at the species level and evaluated relative to general ecology and constraints such as molting and breeding timetables. The advancement of tracking technology provides an opportunity to explore variation in more specific migration tactics within species and their populations as it relates to demographic and environmental factors throughout the annual cycle. We compare migration timing among 4 populations of Bobolink (Dolichonyx oryzivorus) from across the breeding range using data from light-level geolocators. The date of departure from the breeding grounds and the duration of southbound migration differed among breeding populations, and were more variable for eastern breeding populations compared to western populations farther from the main migration corridor. Despite variation in both timing and distance from the corridor among breeding populations, date of arrival at the major southbound stop in the Llanos of South America remained synchronous, but less so than previously described. Weekly flight distances were highly variable and did not differ among populations. Duration of northbound migration did not differ among populations and was half as long as the southbound migration. Our findings show Bobolink populations breeding near the species' relatively narrow migration corridor in the southeastern United States were more variable in terms of how they reached the first lengthy stop in the Llanos, suggesting more flexibility in migration tactics. Breeding locations were not associated, however, with the timing or duration of the remainder of their migratory schedule. Our findings support the hypothesis that food resources, both historical and present, drive and also modify the endogenous migration schedule of this flocking species with a split migration. Received 26 September 2017. Accepted 23 December 2018.
\end{abstract}

Key words: Bobolink, Dolichonyx oryzivorus, geolocators, Llanos, migration tactics, molting grounds, timing

Tácticas de migración en un pájaro migratorio de larga distancia a lo ancho de su rango reproductivo continental

RESUMEN (Spanish) —En el mundo de las aves, las estrategias de migración se comparan frecuentemente a nivel específico, y son evaluadas en relación con su ecología general y sus limitantes como calendarios de muda y reproducción. El avance de la tecnología para el seguimiento de estas aves nos da una oportunidad para explorar la variación de las tácticas de migración más específicas, al interior de las especies y sus poblaciones, y cómo se relacionan con factores demográficos y ambientales a lo largo del ciclo anual. Comparamos la temporalidad de la migración entre 4 poblaciones del tordo arrocero (Dolichonyx oryzivorus) de todo lo ancho de su rango reproductivo por medio del uso de geolocalizadores de nivel de luz. La fecha de partida de sus tierras de reproducción, y la duración de sus migraciones al sur, difieren entre poblaciones reproductivas y fueron más variables para las poblaciones reproductivas del este comparadas con aquellas del oeste, que están más alejadas del corredor migratorio principal. Pese a la variación en la temporalidad y distancia del corredor migratorio entre poblaciones reproductivas, la fecha de llegada al sitio de parada en su ruta hacia el sur, en los Llanos de Sudamérica, siguió siendo sincrónica, aunque menos de lo que había sido descrito previamente. Las distancias de vuelo semanales fueron altamente variables y no difieren entre poblaciones. La duración de la migración hacia el norte tampoco difiere entre poblaciones y tiene la mitad de la duración que la migración hacia el sur. Nuestros hallazgos muestran que las poblaciones de este tordo, que anidan cerca del corredor migratorio relativamente angosto de esta especie en el sureste de los Estados Unidos, fueron más variables en términos de cómo llegaron a la primera parada de cierta duración en los Llanos, sugiriendo una mayor flexibilidad en sus tácticas de migración. Sin embargo, las localidades reproductivas no estuvieron asociadas con la temporalidad o la duración durante el resto de su calendario de migración. Nuestros hallazgos le dan soporte a la hipótesis de que los recursos alimenticios históricos y presentes conducen y modifican el calendario migratorio endógeno de esta especie que migra en parvadas y que tiene una migración en etapas.

Palabras clave: Dolichonyx oryzivorus, geolocalizadores, Llanos, tácticas de migración, temporalidad, territorios de muda, tordo arrocero

Ornithology is defined through questions about variation - if and why variation exists within and between populations. Variation in migration patterns among species in relation to major life history traits such as molt and breeding schedules

${ }^{1}$ Vermont Center for Ecostudies, White River Junction, VT, USA

${ }^{2}$ Department of Biology, Portland State University, Portland, OR, USA

${ }^{3}$ Department of Environmental Studies, University of New England, Biddeford, ME, USA

${ }^{4}$ Environment and Climate Change Canada, Burlington, ON, Canada

* Corresponding author: rrenfrew@vtecostudies.org have been described (e.g., Newton 2008, 2011), but our understanding of intraspecific variation is more limited. Miniaturized geolocators now enable ornithologists to explore variation in the response of migratory birds to their environment in notably greater detail, with greater precision, and in all parts of the annual cycle (López-López 2016). As a result, these devices reveal new facets of species' migration tactics, including the variation in routes, timing, and duration within species.

Long-distance migratory songbirds exhibit remarkable variation in intraspecific migration tactics, generally between breeding populations rather than within populations. For example, the 
southbound migration route of Purple Martin (Progne subis) varied depending on the breeding location spanning $\sim 24^{\circ}$ longitude; more-western birds frequently took a long route through Mexico, while more-eastern birds either flew over the Gulf of Mexico from the Gulf states or from Florida (Fraser et al. 2013). Likewise, in a study of 3 Montagu's Harrier (Circus pygargus) breeding populations spanning $\sim 23^{\circ}$ longitude, migration routes were similar between individuals within the same breeding population, but differed among populations (Trierweiler et al. 2014). European Roller (Coracias garrulus) breeding populations spanning $\sim 40^{\circ}$ longitude used multiple migration routes converging within a $\sim 25^{\circ}$ corridor (Finch et al. 2015). Finally, breeding populations of Wood Thush (Hylocichla mustelina) ranging from Illinois to Vermont (spanning $\sim 20^{\circ}$ longitude) used similar migration routes, crossing the Gulf of Mexico from Florida; however, northbound routes were more variable, with some individuals taking land routes through Mexico rather than flying over the Gulf of Mexico (Stanley et al. 2014).

A greater understanding of migration routes has led to questions about the causes and consequences of variation in migration tactics. Surprisingly, the routes flown by birds may not explain variation in their migration rates (Fraser et al. 2013). Even when migration routes differ among populations, migration timing, duration, distance or speed may not (Trierweiler et al. 2014). Furthermore, spatial and temporal migration patterns such as route similarity among years in non-passerines may differ from those of nocturnal long-distance migrant passerines (Hasselquist et al. 2017).

The Bobolink (Dolichonyx oryzivorus) is a small ( $\sim 30 \mathrm{~g})$ grassland obligate songbird whose breeding distribution spans $70^{\circ}$ longitude across northern North America. It spends roughly 4 months (Dec-Mar) in southern South America, where its distribution spans $10^{\circ}$ latitude (Renfrew et al. 2015). Individuals from breeding populations in Oregon, Nebraska, and Vermont share an eastern migration corridor through Florida, the Caribbean, and the Llanos grasslands of Venezuela and Colombia. The migratory corridor from Florida to Cuba to South America was even named the "Bobolink route" due to their sheer numbers (Cooke 1915). During southbound migration, birds from all 3 populations arrived synchronously in the Llanos for a 3- to 6-week stop before crossing the Amazon Basin to eastern Bolivia, Paraguay, and northeastern Argentina (Renfrew et al. 2013), where they carry out a complete, pre-alternate molt (Renfrew et al. 2011), hereafter referred to as "molting grounds" (they also carry out a complete pre-basic molt on or near the breeding grounds). Bobolinks follow a southward route punctuated by both brief and lengthy stops over a 3-month period to arrive in Argentina, Paraguay, or Bolivia, where they remain until early April (Renfrew et al. 2013). This previous work identified major Bobolink migration stops and molting grounds for some breeding populations (Renfrew et al. 2013), but it did not evaluate the tactics within and among populations that enable them to arrive synchronously in the Llanos in October, and in time for breeding activities in spring.

Here, we use geolocator data from Bobolinks breeding in Oregon, British Columbia, Nebraska, Ontario, and Vermont (spanning $\sim 45^{\circ}$ longitude) to assess variation in southbound and northbound migration tactics across this continent-wide breeding distribution. We predicted that eastern breeding populations (Ontario and Vermont) closer to the main migration corridor would show greater variation in departure date, weekly flying distance, and duration of southbound and northbound migration periods. We predicted that the shorter required travel distance would translate to later average departure from the breeding grounds for eastern breeding populations.

\section{Methods}

\section{Study sites}

We deployed light-level geolocators at 5 sites across the breeding range of Bobolinks: Luther Marsh Wildlife Management Area (WMA) near

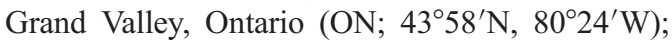
Lumby, British Columbia (BC; $50^{\circ} 14^{\prime} \mathrm{N}$, $118^{\circ} 55^{\prime} \mathrm{W}$ ); northwestern Vermont (VT; $44^{\circ} 23^{\prime} \mathrm{N}$, $73^{\circ} 16^{\prime} \mathrm{W}$ ); south-central Nebraska (NE; $40^{\circ} 48^{\prime} \mathrm{N}$, $\left.98^{\circ} 26^{\prime} \mathrm{W}\right)$; and Malheur National Wildlife Refuge near Princeton, Oregon (OR; $43^{\circ} 16^{\prime} \mathrm{N}, 118^{\circ} 50^{\prime} \mathrm{W}$ ). Data from sites in the United States were originally published in Renfrew et al. (2013); we combined raw geolocator data from that study with data from geolocators deployed and retrieved in Canada, and analyzed all data using the most recent methods (Rakhimberdiev et al. 2017). 


\section{Bird capture and geolocator deployment}

We captured Bobolinks using $12 \mathrm{~m} 36 \mathrm{~mm}$ mesh mist nets placed strategically in areas of relatively high territory density or near known nests. See Renfrew et al. (2013) for methods used to find and net Bobolinks and deploy geolocators at U.S. sites. For sites in Canada, we located nests by walking in lines of 2-6 people across and searching where birds flushed ahead of us. We captured most females by placing 2 nets in a "V" approximately $1 \mathrm{~m}$ from the nest in order to capture them as they approached the nest to incubate eggs or feed young. We captured males using recordings of song and call near the nets, often flushing them into the nets. During years of geolocator deployment, each captured Bobolink received a unique color band combination. We collected standard measurements and noted reproductive condition. Upon recapture we did not replace missing color bands, nor add color bands to birds that had not previously been color banded. When attempting to recapture Bobolinks, we immediately released non-target birds.

In 2013 we deployed 0.9 g Mk-12 light-level geolocators developed by Migrate Technology on 20 females and 20 males in ON. Light sensors were located at the tip of a $15 \mathrm{~mm}$ stalk that rose above the backpack unit at a $30^{\circ}$ angle. We used a leg loop harness system (Rappole and Tipton 1991) with Teflon 0.1 inch-wide ribbon for a harness (total mass $=1.0-1.1 \mathrm{~g}$ ), and applied fastdrying glue to the knot and near the entrance of the geolocator tunnel to prevent slippage. In 2014, we deployed the same model geolocators on Bobolinks using the same methods in ON (8 males, 13 females) and in $\mathrm{BC}$ (9 males and 5 females).

Between mid-May and mid-June of 2014 and 2015 we relocated Bobolinks carrying geolocators by observing the geolocator on the back or by resighting color bands. We target-netted all individuals potentially carrying a geolocator even if we could not see evidence of a geolocator on the bird from a distance. In $\mathrm{ON}$ and $\mathrm{BC}$ most Bobolinks removed one or more of their color bands following deployment; we therefore recaptured all Bobolinks seen with a metal band. Nesting individuals were netted near nests after they were at least midway through the incubation period to reduce the risk of abandonment.

\section{Analysis}

We retrieved 5 geolocators: 4 in $\mathrm{ON}$ and 1 in BC. An additional Bobolink returned to $\mathrm{BC}$ without its geolocator. We analyzed the data we downloaded from $\mathrm{ON}$ and $\mathrm{BC}$ along with the raw data from 7, 4, and 4 geolocators on 14 Bobolinks (1 individual in NE carried a different geolocator in each of 2 consecutive years) deployed in NE, VT, and OR, respectively, from a previous study (Renfrew et al. 2013). Only 4 of the geolocators were worn by females: 2 from $\mathrm{ON}$ and 2 from OR. For some analyses we grouped data from OR and BC (referred to as "West") because of low sample sizes for these sites. We use the term "eastern populations" to refer to Bobolinks from $\mathrm{ON}$ and VT sites. Sample sizes were too small to allow a comparison of male and female tactics.

We detected twilights with the BAStag package (Wotherspoon et al. 2013) in R 3.2.3 (R Core Team 2015) using the recommended light threshold value of 1.5. We removed extraneous sunrises and sunsets due to temporary shading, and flagged by the program as problematic.

For all twilight data we used the FLightR package (Rakhimberdiev et al. 2015, 2017) in R to obtain location estimates. By optimizing a hidden Markov model over the entire tracked period, this method estimates the probability distribution of the position of a bird to obtain the most probable migration route. We used recommended default values, including a mean distance moved of 300 $\mathrm{km}$ with $500 \mathrm{~km}$ SD (Rakhimberdiev et al. 2015, 2017). For one individual that took an especially long oceanic flight, however, we ran the model again with a doubled mean flight distance $(600$ $\mathrm{km})$ to allow for its longer, non-interrupted flight. We omitted outliers with Tsoutliers ( $\mathrm{R}$ package, see Rakhimberdiev et al. 2015). FLightR produces both median and mean estimated positions for each twilight; we used median positions because they produced fewer sedentary locations over the ocean.

FLightR generates the posterior probability for positions as a distribution of particles over a spatial grid that excludes ocean using a land mask, and their credible intervals (CIs) as a measure of uncertainty (Rakhimberdiev et al. 2017). The large geographic range of the Bobolink required that we use $100 \mathrm{~km}$ as a distance between grid nodes to remain within computer computational limits. 
Table 1. Rules used for defining periods of migration, stops, and winter/austral summer molting locations based on geolocator data for Bobolink.

\begin{tabular}{lc}
\hline \multicolumn{1}{c}{ Migration stage } & \multicolumn{1}{c}{ Definition rules } \\
\hline $\begin{array}{l}\text { Depart breeding grounds, } \\
\text { begin southbound migration }\end{array}$ & $>250 \mathrm{~km}$ from breeding site with $>50 \mathrm{~km}$ longitudinal change for $>3 \mathrm{~d}$ \\
Southbound staging period & $>250 \mathrm{~km}$ (or non-overlapping error) longitudinal change from breeding location, \\
& southbound movements lacking or not consistent (1 d or less), remains for at least 1 \\
& week \\
End southbound migration & Within 250 km of molting grounds \\
Molting grounds & Location where bird remains within $100 \mathrm{~km}$ for $>3 \mathrm{~d}$ after 20 Jan \\
Begin northbound migration & $>250 \mathrm{~km}$ from molting grounds for $>3 \mathrm{~d}$ \\
Northbound staging period & $>250 \mathrm{~km}$ from molting grounds $>3 \mathrm{~d}$ after 1 Mar, northbound movements not \\
& consistent $(1 \mathrm{~d}$ or less) \\
End northbound migration & Within $250 \mathrm{~km}$ of breeding site or when movements stop at breeding site longitude \\
\hline
\end{tabular}

Animal positions are assigned to the closest node in the grid. We calibrated data from each geolocator using the first $30 \mathrm{~d}$ after the deployment, when the birds were at a known location (on territory), whenever possible. When the data indicated the bird may have been moving within the $30 \mathrm{~d}$, we shortened the calibration period by up to $15 \mathrm{~d}$ to include only periods when the bird appeared sedentary at its breeding site. Bobolinks inhabit open grasslands throughout the year, and we assumed that influences of vegetation density and weather on shading were consistent throughout deployment. Average error of median location values during calibration periods on the breeding grounds was low (generally $<50 \mathrm{~km}$ in latitude or in longitude), in part because bird locations adhere to a $100 \mathrm{~km}$ grid.

We separated southbound and northbound migration from breeding and winter (austral summer) molting grounds for each individual based on rules that defined when the bird was migrating (Table 1). Long stops were considered part of migration, except the "molting grounds" location during which the bird would carry out its prealternate molt in January-March (Renfrew et al. 2013). More technically, molting grounds were defined as the location where a bird remained within $100 \mathrm{~km}$ for $>3 \mathrm{~d}$ after 20 January. Some birds left breeding or molting grounds and stopped in nearby areas before migrating significant distances, while others immediately flew great distances directly from their breeding grounds. The error associated with lightlevel geolocator data can make it difficult to determine exactly when birds begin migrating until they make lengthy or consistent flights. Southbound migration occurs close to the equinox, when latitudinal positions are unreliable because day length varies little across latitudes, but longitudinal movements can indicate migration. We evaluated differences in movement tactics using only movements $>200 \mathrm{~km}$, to reduce the chance of including movements that were due to error, as well as actual, local movements during stops. To consistently define southbound and northbound migration departures, we used rules (Table 1). To make statistical comparisons of migration timing among breeding populations, we used Kruskal-Wallis tests on dates of departure from breeding grounds and on the duration of migration between breeding and molting grounds.

To determine locations of individuals during migration and relative densities of their locations, we estimated fixed kernel densities using the spatial analyst tool in ArcMap 10.3.1 (ESRI 2015) based on point locations for all individuals combined, for southbound migration and for northbound migration. We first removed known stops by removing multiple consecutive points with the same latitude and longitude. Then, following Renfrew et al. (2013), we used a search radius of $250 \mathrm{~km}$ and a grid cell size of $2 \mathrm{~km}$. We present kernel densities encompassing 50\%, 75\%, and $90 \%$ of the maximum density. To draw migration routes we used Tracking Analyst in ArcMap (ESRI 2015).

\section{Results}

Geolocator data from Bobolinks breeding in Canada reinforce the existence of a migration 

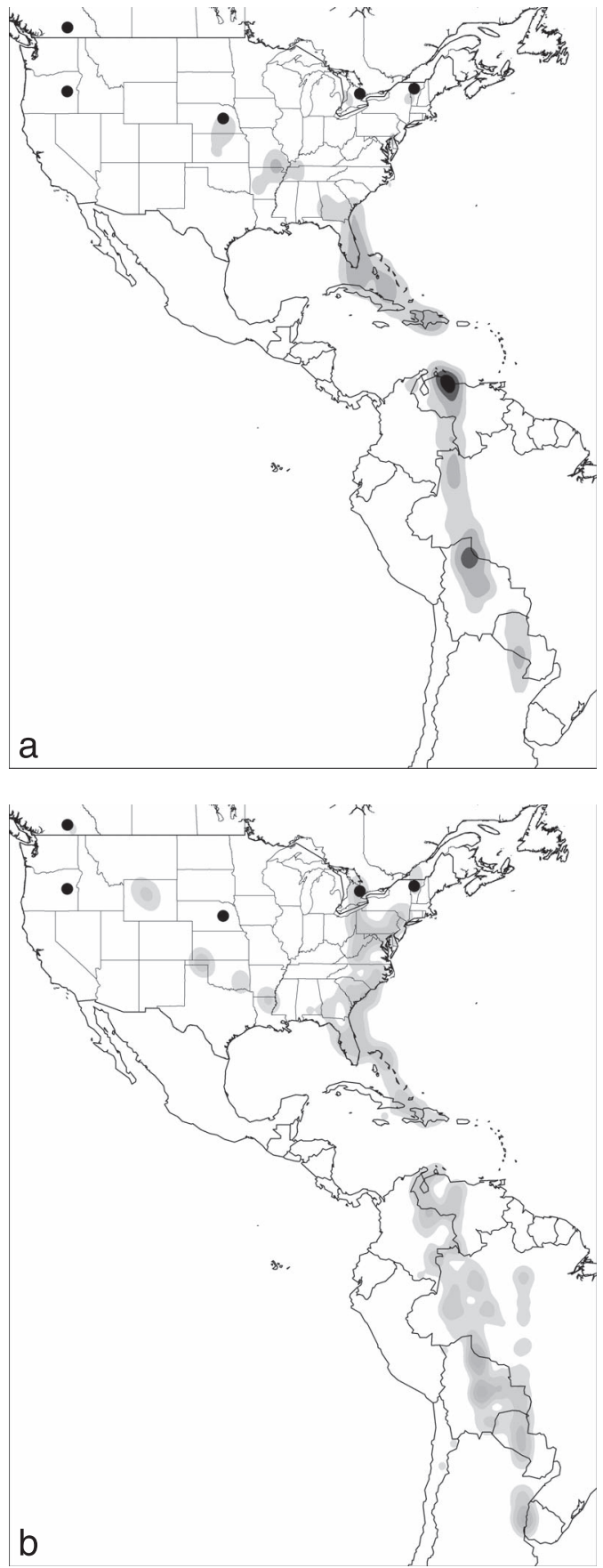

Figure 1. Migration routes for (a) southbound $(n=19)$ and (b) northbound $(n=7)$ Bobolinks based on light-level geolocator data, using kernel densities encompassing 50\%, $75 \%$, and $90 \%$ of the maximum density. Black dots indicate breeding locations. corridor that is used by most of the global population (Hamilton 1962, Renfrew et al. 2013). Northbound migration routes greatly overlapped with the southbound migration route, but some regions were occupied more during either southbound or northbound migration, particularly in Bolivia and Colombia (Fig. 1).

Migration timing varied among populations of Bobolinks across the breeding range. Date of departure from the breeding grounds differed among the populations (Kruskal-Wallis chisquared $=8.79, \mathrm{df}=3, P=0.03$ ), largely due to Nebraska birds that on average left earlier than other populations (Table 2, Fig. 2a). Bobolinks from eastern breeding populations (ON and VT) varied more in breeding grounds departure date compared to NE and West (OR and BC combined) populations (Fig. 2a). Departures spanned $10 \mathrm{~d}$ in OR and BC, $17 \mathrm{~d}$ in Nebraska, and 5-6 weeks in $\mathrm{ON}$ and VT.

Duration of southbound migration tended to differ among Bobolink breeding populations (Kruskal-Wallis chi-squared $=7.38, \mathrm{df}=3, P=$ 0.06 ; Fig. 2b). Eastern populations varied more in the time spent migrating from breeding to molting grounds compared to the 3 western sites (NE, OR, and $\mathrm{BC})$. Associated with this pattern is the range in arrival dates to the molting grounds, which spanned 2 months for eastern breeding populations (range: 25 Nov-23 Jan) compared to less than 1 month for breeding populations in NE, OR, and BC (range: 1-26 Dec). The duration of this migration was shortest for the NE population (Fig. 2b, 3a). Individuals from eastern populations were more likely to stage in areas $>250 \mathrm{~km}$ from their breeding location for $1-3$ weeks before making consistent southbound flights (Table 2).

Despite variability in departure dates and duration of southbound migration, the range in the dates of arrival to the Llanos was similar among breeding populations (range in dates of arrival: $15,17,16$, and $17 \mathrm{~d}$ for birds breeding in VT, ON, NE, and West, respectively; Table 2). The 2 Bobolinks (BC and VT) that arrived latest to the Llanos first spent 18 and $11 \mathrm{~d}$, respectively, in the Caribbean before continuing to the Llanos.

Overall, the duration of northbound migration from molting to breeding grounds was half as long as southbound migration (10 weeks vs. 20 weeks). There was little difference in northbound duration 
Table 2. Departure from and arrival to breeding grounds and winter/austral summer molting areas for Bobolinks based on light-level geolocator ("Geo") data. An asterisk indicates the same bird that was tracked for 2 yr.

\begin{tabular}{|c|c|c|c|c|c|c|c|c|c|}
\hline Geolocator & $\begin{array}{c}\text { Breeding } \\
\text { site }\end{array}$ & Sex & $\begin{array}{c}\text { Depart } \\
\text { breeding } \\
\text { grounds }\end{array}$ & $\begin{array}{l}\text { Southbound } \\
\text { staging }\end{array}$ & $\begin{array}{c}\text { Arrive } \\
\text { Venezuela }\end{array}$ & $\begin{array}{l}\text { Arrive } \\
\text { molting } \\
\text { grounds }\end{array}$ & $\begin{array}{l}\text { Depart } \\
\text { molting } \\
\text { grounds }\end{array}$ & $\begin{array}{l}\text { Northbound } \\
\text { staging }\end{array}$ & $\begin{array}{c}\text { Arrive } \\
\text { breeding } \\
\text { grounds }\end{array}$ \\
\hline D694 & $\mathrm{BC}$ & M & 6 Sep & & 21 Oct & $11 \mathrm{Dec}$ & 31 Mar & Until 22 Apr & 31 May \\
\hline 13611 & OR & $\mathrm{F}$ & 1 Sep & & 13 Oct & $2 \mathrm{Dec}$ & Geo failed $16 \mathrm{Feb}$ & & - \\
\hline 13623 & OR & $\mathrm{F}$ & 6 Sep & & 4 Oct & $20 \mathrm{Dec}$ & Geo failed 20 Mar & & 一 \\
\hline 13597 & OR & M & $1 \mathrm{Sep}$ & & 4 Oct & $26 \mathrm{Dec}$ & Geo failed 15 Mar & & - \\
\hline 13612 & OR & M & 27 Aug & 27 Aug-10 Sept & 10 Oct & $6 \mathrm{Dec}$ & Geo failed 1 Jan & & - \\
\hline 13627 & $\mathrm{NE}$ & M & 11 Sep & & 3 Oct & $25 \mathrm{Dec}$ & Geo failed 4 Mar & & - \\
\hline 13614 & $\mathrm{NE}$ & $\mathrm{M}$ & 15 Sep & & 12 Oct & $6 \mathrm{Dec}$ & Geo failed 18 Mar & & - \\
\hline 13601 & $\mathrm{NE}$ & M & $16 \mathrm{Sep}$ & & 8 Oct & $6 \mathrm{Dec}$ & $6 \mathrm{Apr}$ & & $\begin{array}{c}\text { Geo failed } \\
24 \mathrm{Apr}\end{array}$ \\
\hline 13600 & $\mathrm{NE}$ & M & $16 \mathrm{Sep}$ & 16-25 Sept & 6 Oct & $10 \mathrm{Dec}$ & $3 \mathrm{Apr}$ & 3-16 Apr & $\begin{array}{c}\text { Geo failed } \\
8 \text { May }\end{array}$ \\
\hline 13626 & $\mathrm{NE}$ & $\mathrm{M}$ & 17 Sep & & $4 \mathrm{Oct}$ & $11 \mathrm{Dec}$ & Geo failed 4 Apr & & - \\
\hline $20045^{*}$ & $\mathrm{NE}$ & M & 22 Sep & & 19 Oct & $1 \mathrm{Dec}$ & 7 Apr or earlier & & 19 May \\
\hline $13608^{*}$ & $\mathrm{NE}$ & $\mathrm{M}$ & 28 Sep & & 10 Oct & $2 \mathrm{Dec}$ & Geo failed $10 \mathrm{Feb}$ & & - \\
\hline D706 & ON & $\mathrm{F}$ & 19 Aug & 20 Aug-27 Aug & 10 Oct & $25 \mathrm{Nov}$ & 22 Mar & 22 Mar-22 Apr & 17 May \\
\hline D784 & $\mathrm{ON}$ & $\mathrm{F}$ & 9 Sep & & 7 Oct & 15 Jan & $25 \mathrm{Apr}$ & & 29 May \\
\hline D785 & $\mathrm{ON}$ & M & 12 Aug & 25 Aug-5 Sept & 23 Sep & $18 \mathrm{Dec}$ & 21 Mar & 23 Mar-9 Apr & 9 May \\
\hline D769 & ON & M & 25 Sep & & 3 Oct & 2 Jan & $11 \mathrm{Apr}$ & & 12 May \\
\hline 13654 & VT & M & 5 Aug & 5-26 Aug & 4 Oct & 18 Nov & Geo failed $3 \mathrm{Feb}$ & & - \\
\hline 13648 & VT & M & 3 Sep & & 19 Oct & 18 Nov & Geo failed $20 \mathrm{Feb}$ & & - \\
\hline 7779 & VT & M & 10 Sep & $\begin{array}{l}\text { 11-17 Sept, } \\
18-27 \text { Sept }\end{array}$ & 7 Oct & $16 \mathrm{Dec}$ & 27 Mar & & 21 May \\
\hline 7798 & VT & M & 16 Sep & 16-27 Sept & 5 Oct & 23 Jan & 7 Mar & $7-22$ Mar & 12 May \\
\hline
\end{tabular}

among breeding populations, except the West, with migration of only 1 bird represented (Fig. 3b).

During periods of movement location uncertainty increased. The average credible interval of latitude and longitude for periods of movement (excluding when the bird was absolutely stationary) for all geolocators combined spanned 1,140 $\mathrm{km}$ latitude and $404 \mathrm{~km}$ longitude for southbound migration, and $1,270 \mathrm{~km}$ latitude and $415 \mathrm{~km}$ longitude for northbound migration.

Weekly flying distance was highly variable during southbound and northbound migration among sites (Fig. 4), with no indication that it was more variable in eastern compared to western breeding populations. Within each site, individuals varied greatly in their weekly flying distance. A male Bobolink with 2 consecutive years of southbound migration data also varied its weekly flying distance between years, although the timing of short- and long-distance flights was similar at a coarse temporal scale (Fig. 5).

Our data revealed long flights, stops, and molting grounds, including flights not previously recorded by geolocators for Bobolink. Geolocators we deployed in Canada show that flights of over $1,000 \mathrm{~km} / \mathrm{d}$, first documented in the United States (Renfrew et al. 2013) for Bobolinks migrating south, are routine during crossings over the Amazon basin, the Caribbean, the Rocky Mountains, the Chaco in Bolivia, and during oceanic crossings. Bobolinks carrying geolocators routinely covered distances $\geq 1,000 \mathrm{~km}$ within a $12 \mathrm{~h}$ period (Table 3). The longest flights recorded included an estimated 4,660 km within $36 \mathrm{~h}$ on $6-$ 7 October 2009 by a male Bobolink from Vermont. This journey included a $<24-\mathrm{h}$ stopover in Bermuda. The small error in the longitude of points near Bermuda rule out migration along the coast, and the change in longitude during the presumed flight indicate movement, whereas points before and after do not change in longitude for at least $2 \mathrm{~d}$. Although the latitude estimates are close enough to the equinox to result in substantial error, there were multiple closely spaced points before and after the presumed oceanic crossing with small errors. Once the bird arrived in South 
a

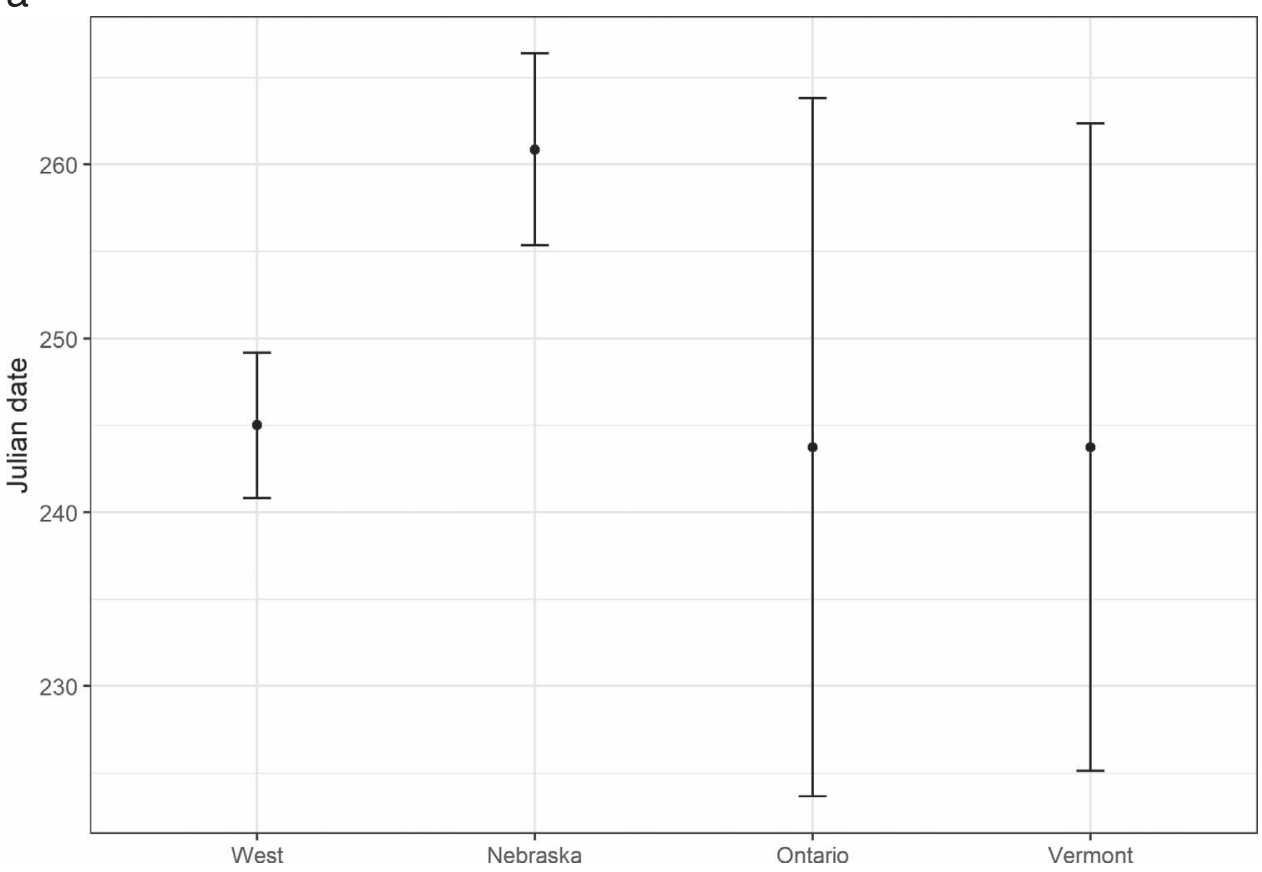

b

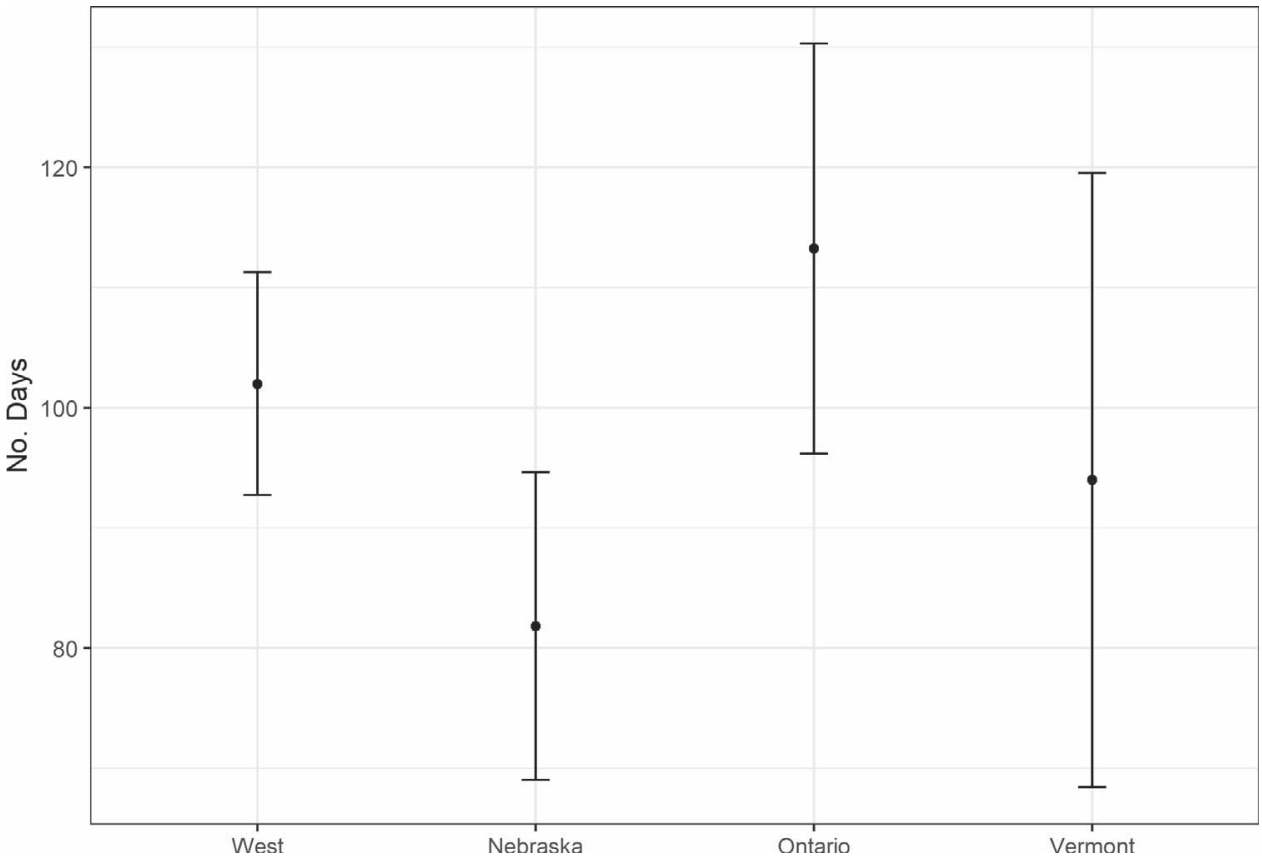

Figure 2. Mean and SD of (a) Julian date of departure from breeding grounds and (b) number of days between departure from breeding grounds in the West (Oregon and British Columbia; $n=5)$, Nebraska $(n=7)$, Ontario $(n=4)$, and Vermont $(n$ $=4$ ) breeding grounds and arrival at winter/austral summer molting grounds for Bobolinks, based on light-level geolocator data. 
a

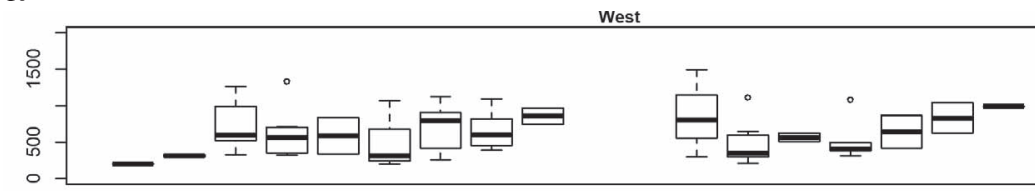

Nebraska

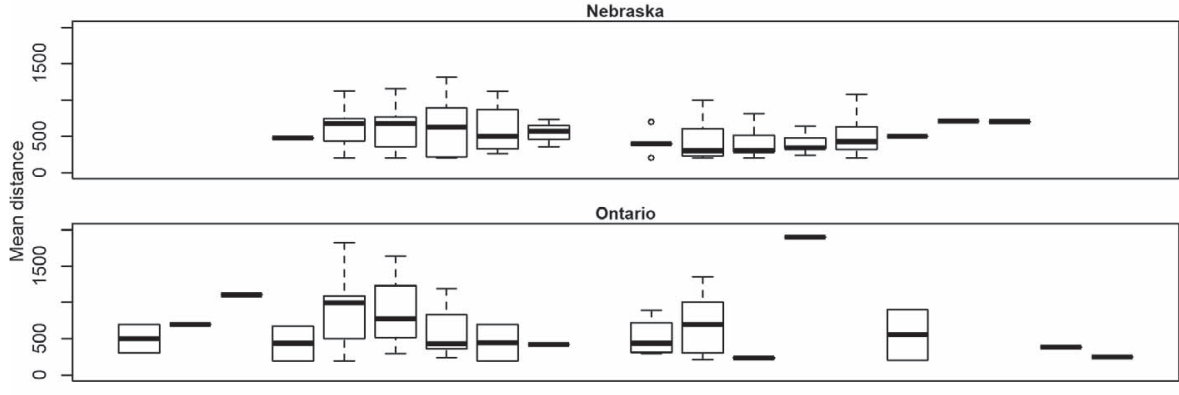

Vermont

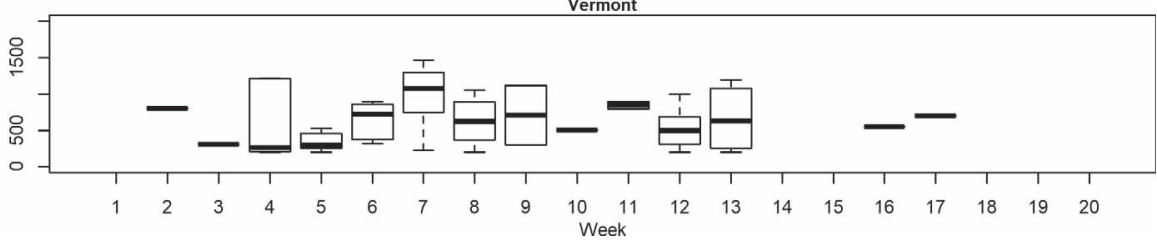

b
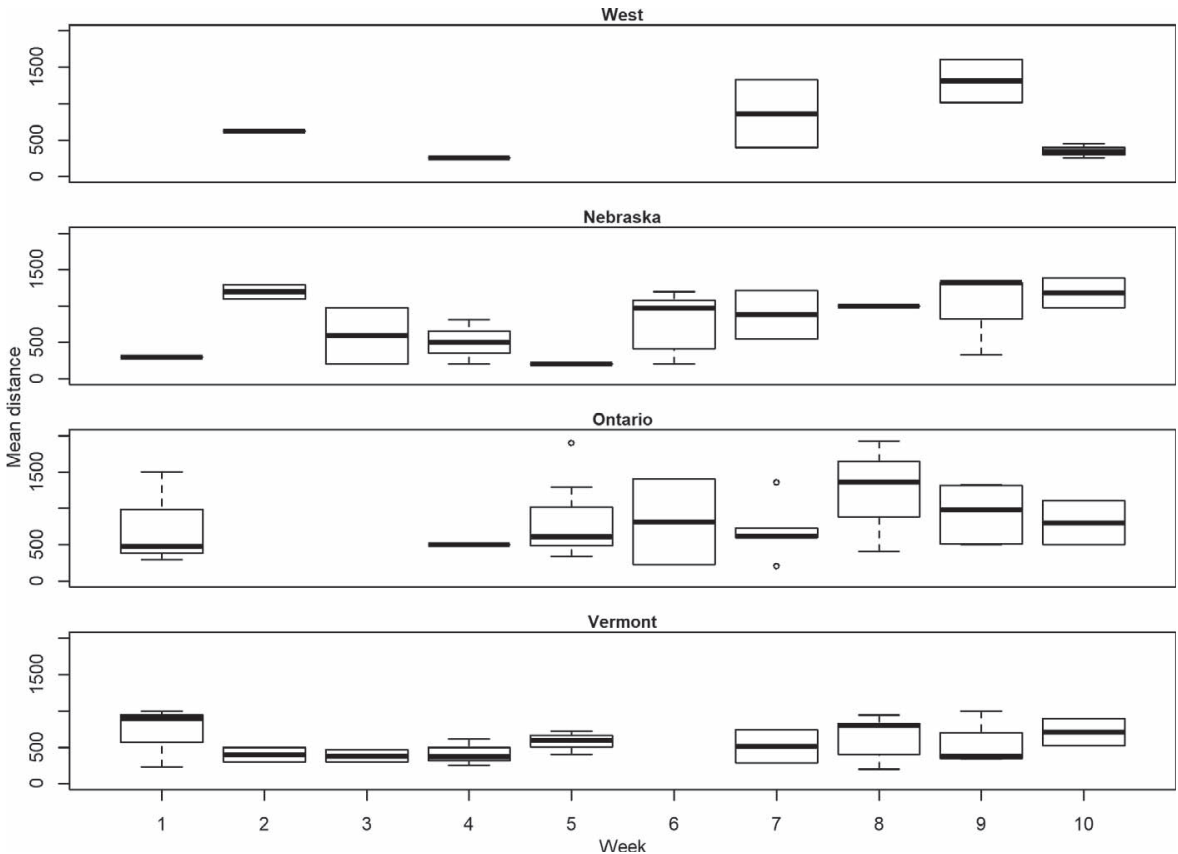

Figure 3. Variation in the timing of movements and distances travelled by Bobolinks from different breeding sites. Boxplots of distances $>200 \mathrm{~km}$ flown per week by Bobolinks during (a) southbound migration (15 Aug-15 Jan) and (b) northbound migration (15 Mar-15 May). "West" comprises 4 Bobolinks breeding in Oregon plus one male breeding in British Columbia. The lack of movement during weeks 10-12 in panel (a) coincide with a multi-week stop in the Llanos. 
a
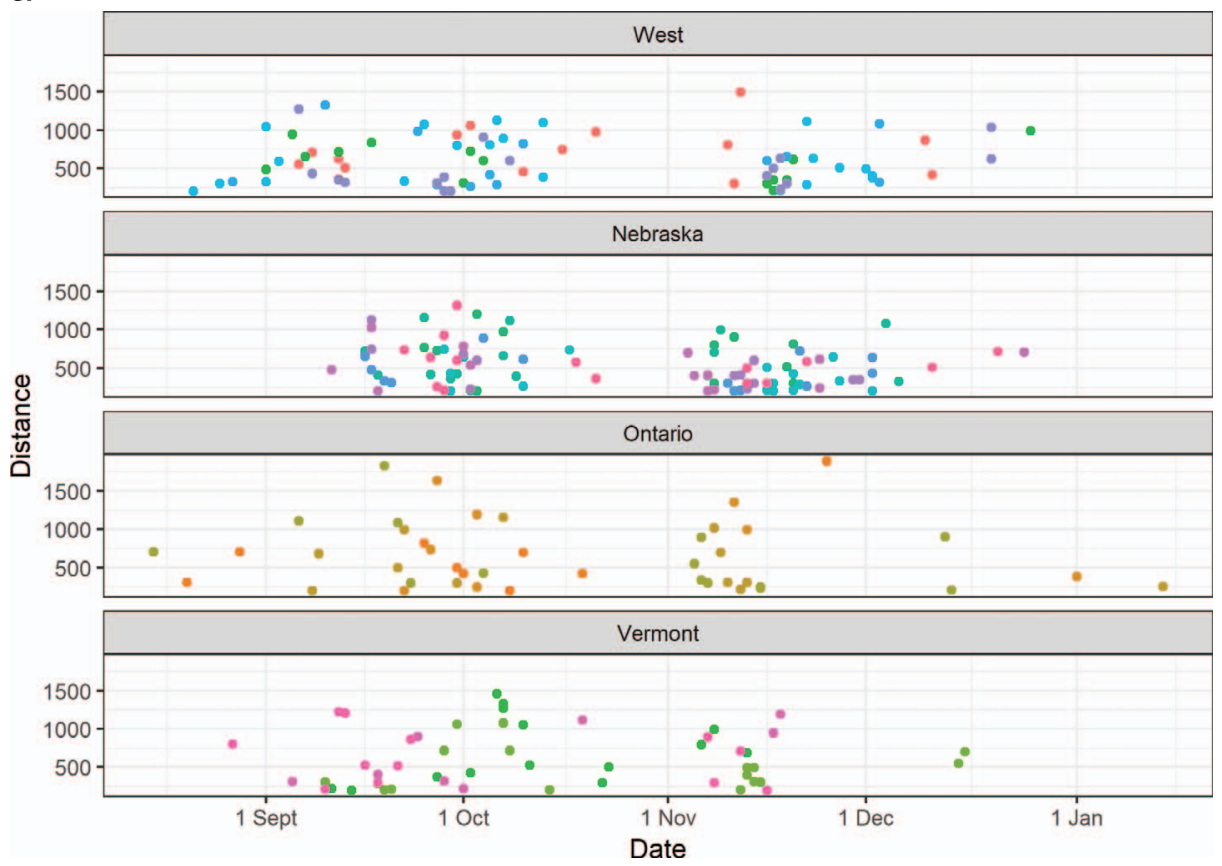

b
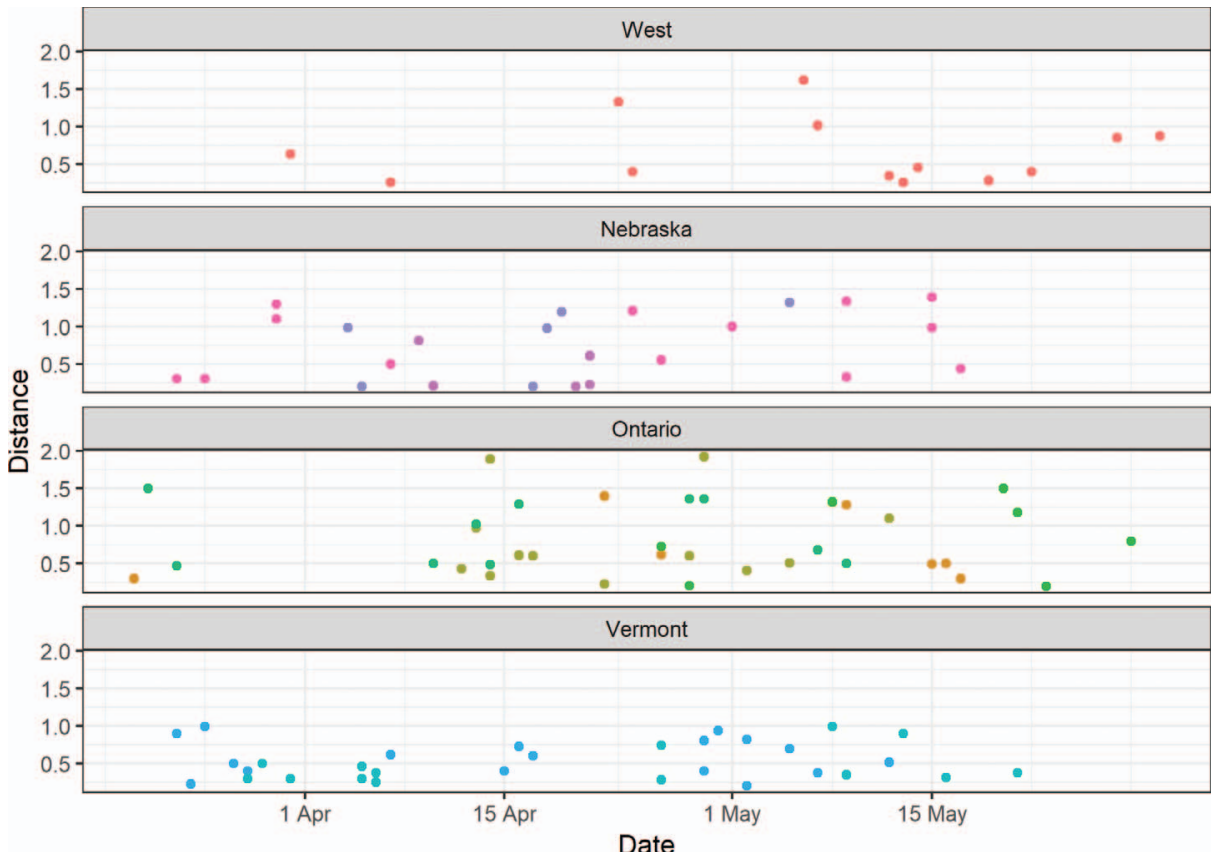

Figure 4. Distances $>200 \mathrm{~km}$ flown by individual Bobolinks during (a) southbound $(n=19)$ and (b) northbound ( $n=10)$ migration, color-coded by individual geolocator number. "West" comprises 4 Bobolinks breeding in Oregon plus one Bobolink breeding in BC (the only bird for this group with northbound data). Each color represents a different individual, except geo 20045 and geo 13608, which are 2 consecutive years for the same bird. See Table 2 for specific details on each bird. Birds with truncated northbound data were carrying geolocators that failed early. 


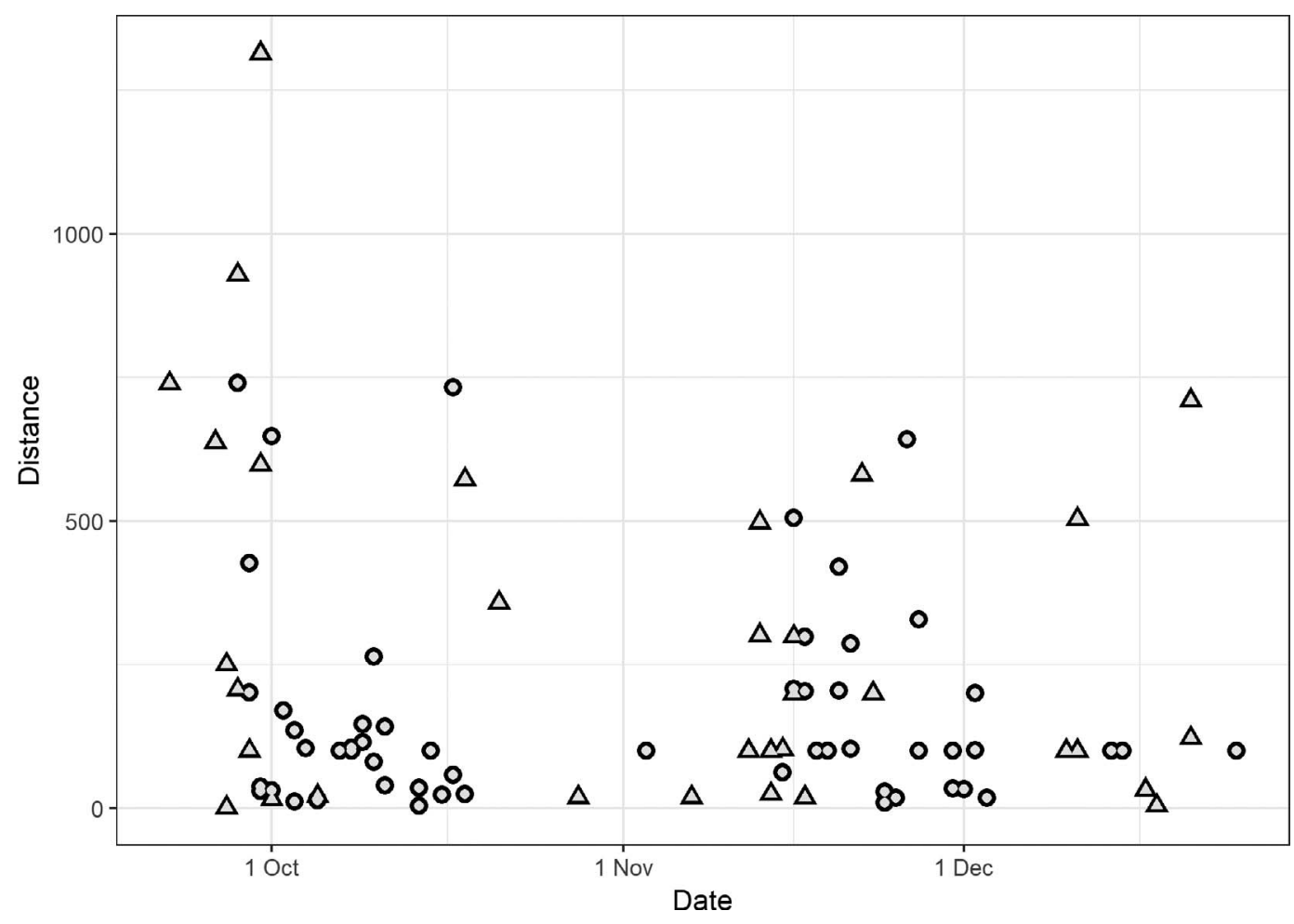

Figure 5. Distances moved during southbound migration of the same individual Bobolink in 2 consecutive years (circle $=$ year 1, triangle = year 2). The bird was breeding in Nebraska, and had similar migration routes and winter/austral summer molting grounds between the 2 years (Renfrew et al. 2013).

America, the upper error credible interval was within South America, indicating that the oceanic crossing was completed. Two birds from ON flew from the Colombia-Venezuela border to Florida, $\sim 2,500-2,600 \mathrm{~km}$, within $2 \mathrm{~d}$. Lengthy flights also occurred when birds traveled across the Chaco to

Table 3. Number of $>1,000-\mathrm{km}$ flights by Bobolinks $(N=$ 20) within $12 \mathrm{~h}$ of birds from 4 sites in the United States and Canada, based on light-level geolocator data. The "West" site comprises 1 and 4 geolocators from British Colombia and Oregon, respectively.

\begin{tabular}{lccc} 
& & \multicolumn{2}{c}{ Number of flights $>1,000 \mathrm{~km}$ in $<12 \mathrm{~h}$} \\
\cline { 3 - 4 } \multicolumn{1}{c}{ Site } & $n$ & Southbound & Northbound \\
\hline Ontario & 4 & 10 & 12 \\
Vermont & 4 & 11 & 8 \\
Nebraska & $7^{\mathrm{a}}$ & 8 & 0 \\
West (OR and BC) & 5 & 11 & 3 \\
TOTAL & 20 & 40 & 23 \\
\hline
\end{tabular}

${ }^{\text {a }}$ One individual carried 2 different geolocators in each of 2 years. molting grounds in Argentina, following a stop in Bolivia. Finally, one female occupied molting grounds farther north than any Bobolink carrying a geolocator to date, in the southern Amazon (state of Amazonas) in Brazil $\left(7^{\circ} 11^{\prime} \mathrm{S}, 68^{\circ} 57^{\prime} \mathrm{W}\right)$.

We did not band and track birds without geolocators in order to formally compare return rates. In ON, 11 of the 61 birds on which we deployed geolocators were resighted the following year (one was resighted 2 yr later); of these, 5 still carried their geolocators, and 4 were captured (1 female carrying a geolocator was seen only once and was not captured). Therefore, $18 \%$ of Bobolinks with geolocators were resighted in subsequent years in ON; of those, $45 \%$ had retained their geolocator. At the 3 U.S. sites, $10 \%$ and $21 \%$ of deployed geolocators $(n=105)$ were recovered in years 2 and 3 of the study, respectively; an increase after improvements were made to the harness (Renfrew et al. 2013). 


\section{Discussion}

\section{Reinforced patterns and new discoveries}

Light-level geolocation data from Bobolinks breeding in Canada reinforce the species' general movement path (Nathan et al. 2008) described earlier (Renfrew et al. 2013). During the southbound migration Bobolinks undergo a "split migration," defined by a long stop (in the Llanos) that interrupts the migration from breeding to molting grounds to maximize vegetative growth (Renfrew et al. 2013) and, thereby, food resources (Newton 2008).

We show for the first time the northbound migration route of Bobolinks from across the breeding range, and refine the depiction of the southbound migration route. Southbound and northbound routes overlap from Florida south to create a longitudinally compact migration corridor. Some regions were used more in a given season. For example, some southbound Bobolinks that moved through the far eastern edge of Colombia and western Venezuela were often farther west when they were flying back to their breeding grounds. In Bolivia, Bobolinks always traveled through the northeastern part of the country, but regions farther south and east were used more often during northbound migration.

A female breeding in ON carried out her prealternate molt in western Brazil, a region north of the main Bobolink distribution during austral summer. The region has limited open habitat, and to our knowledge, no records of Bobolinks outside of migration periods. There are scant records of Bobolinks at similar latitudes in Peru (Ridgely et al. 2003; RS Ridgely, Rainforest Trust, 2005, pers. comm.), suggesting the region may host a small proportion of the population. Northern locations could represent a northward shift selected for under changing climate conditions (Coppack and Pulido 2004, Woodworth et al. 2016). Alternatively, the weight of the geolocator may have forced the bird to truncate her migration (Hupp et al. 2015; but see Peterson et al. 2015); however, she was able to make long flights (e.g., $\sim 2,500 \mathrm{~km}$ within $1.5 \mathrm{~d}$ ).

\section{Variability in migration schedules}

Our data from geolocators suggest there is more variability in the migration timetables of easterly Bobolink breeding populations compared to pop- ulations farther from the species' main migration corridor. Most notably, eastern populations varied more in their departure date from the breeding grounds and in the duration of their migration from breeding to molting grounds compared to western populations farther from the migration corridor. We might expect variability in the migration schedule to be inversely related to migration distance for long-distance migratory bird species with large breeding or nonbreeding ranges. However, this pattern may not be seen in species that migrate extremely long distances and have greater temporal constraints. For example, Bartailed Godwits (Limosa lapponica baueri) migrate over $32,000 \mathrm{~km}$ annually, and their populations were found to vary little in the range of departure days from the breeding grounds regardless of breeding location (Conklin et al. 2010).

Flexibility in the migration schedule allows birds to respond to environmental variability (Marra et al. 2005, Calvert et al. 2011, Stanley et al. 2012) and is an important characteristic for long-distance migrants with limited ability to respond to rapidly changing conditions (Coppack and Pulido 2004, Marra et al. 2005, Hurlbert and Liang 2012, Stanley et al. 2012). Although we did not measure it directly in this study, the lack of daily synchronization in the movements of individual birds (Fig. 4) suggests flexibility of migration tactics. Flight speed and stopover duration can vary among individuals and at the population level, influenced by factors such as body size and condition, geographic features, weather, carryover effects, and distribution and quality of suitable stopover habitat. Individual timing may even vary from year to year (Vardanis et al. 2011, Stanley et al. 2012, Hasselquist et al. 2017), as we found for a Bobolink we tracked for 2 yr.

Evaluating the relationship between reproductive parameters, body condition, and departure dates would shed light on whether Bobolink migration schedules are influenced by breeding activities. The option to leave the breeding grounds later may afford opportunities to renest later in the season, prospect for future breeding sites (Nocera et al. 2006), and fatten for migration, increasing the chance of survival during a period of the annual cycle when mortality is a likely contributor to population size (Newton 2006). Effects of breeding success or phenology on 
migration timing for other avian species have been equivocal. Departure from breeding grounds was not associated with breeding success or renesting for Bar-tailed Godwit (Conklin et al. 2010). Timing of early southbound migration (but not arrival on wintering grounds) was associated with nesting phenology and subsequent molt phenology in Wood Thush (Stutchbury et al. 2011). For many species, late breeding activities can overlap with molting so as not to delay southbound migration (Newton 2008). A later departure date may, however, be correlated with poor post-breeding body condition (Stutchbury et al. 2011).

Despite variability among Bobolink breeding populations in their departure from breeding grounds and in the duration of their southbound migration, arrival to the species' longest (3- to 6week) stop in the Llanos of Venezuela and Colombia remained generally synchronous, as with Renfrew et al. (2013). However, data from 2 new sites in this study suggests more variable timing: one Bobolink from VT and the Bobolink from $\mathrm{BC}$ arrived outside of the range of arrival dates in the previous study (23 Sept and 21 Oct, respectively; Table 2). The $\mathrm{BC}$ bird had the longest distance to travel and (along with one bird from VT) took the most time to travel to Venezuela. The approximate straight-line distance from the southeastern tip of Florida where most of the global Bobolink population passes is roughly 2,150, 2,350, and 2,400 km for VT, ON, and NE breeding sites, respectively, while the distance to West sites (OR and BC) is $4,000 \mathrm{~km}$ or more. Individuals may employ different tactics to arrive at a time that optimizes reliable resources. For example, Bobolinks breeding in NE and VT left the breeding grounds up to 3 weeks later and spent less time migrating to the Llanos compared to populations breeding in $\mathrm{ON}$ and the West. More research is needed to determine whether limitations on the time allotted for migration in the annual cycle imposes limits on migration distance and ultimately seasonal distribution of Bobolinks.

For this long-distance migratory species, the proximity of a breeding site to the migration corridor was not related to the mean departure date from breeding grounds nor to the duration of migration to or from the molting grounds. If distance to the migration corridor dictated migration strategy, we would predict that individuals from $\mathrm{ON}$ would have left breeding sites later than individuals from West sites, but that was not the case based on the rules we used to define departure. A study of Bar-tailed Godwits showed a strong correlation between migration timing and breeding latitude (distance to wintering grounds), with northerly populations consistently arriving to and leaving from breeding, migration, and wintering areas later throughout the annual cycle (Conklin et al. 2010). Breeding region of Purple Martin was also correlated with date of arrival at stops (Stutchbury et al. 2016b, Van Loon et al. 2017). Our findings for Bobolink, however, are consistent with research on Wood Thush that show a variable southbound migration schedule that is not associated with breeding location (Stutchbury et al. 2011).

Renfrew et al. (2013) found that for Bobolinks breeding in OR, far from the migration corridor, the time spent traveling to their wintering grounds was greater than for Bobolinks breeding in VT or $\mathrm{NE}$, closer to the migration corridor. In this study, however, the $\mathrm{ON}$ breeding population took longer to arrive to molting grounds compared to that same OR population far from the migration corridor. The departure date from the stop in the Llanos and additional stops closer to the molting grounds impact the total time spent migrating. Similarly, Stutchbury et al. (2011) found that for Wood Thush the length of stopovers most impacted arrival dates on molting grounds, rather than breeding location.

The duration of spring (northbound) migration for most long-distance migrants is shorter than fall (southbound) migration (Newton 2008, Schmaljohann et al. 2012, McKinnon et al. 2013), and for Bobolinks we found the former to last about half as long as the latter. Any differences in mean duration or variability in duration of northbound migration among breeding populations are too subtle to be detected with the small sample sizes in our study, as birds are under considerably more pressure to reach the breeding grounds and to take advantage of the flush of resources and establish territories (Newton 2008). Northbound migration schedule of some species may be under endogenous control (Stanley et al. 2012), modified in at least some species by environmental pressures that influence phenotypic variation (Studds and Marra 2011).

The greater variability we found in the timing of migration for Bobolink populations close to 
(compared to far from) the migration corridor did not translate to greater variability in weekly flying distance. During southbound and northbound migrations, sample sizes prevented formal testing of differences in rates of travel among breeding populations. The distance Bobolinks must travel to breeding grounds may influence arrival at breeding grounds or rates of travel, particularly late in northbound migration. Although travel from Florida is only $<250 \mathrm{~km}$ more for Bobolinks flying to NE than to ON or VT, they may fly greater distances per week late in the season to compensate (Fig. 3b). The male breeding in BC made several short flights for 3 weeks in the spring from FL to its breeding site (Fig. 4b), arriving at the breeding site by 31 May. Breeding phenology at western sites is delayed compared to eastern sites (Wittenberger 1978, Renfrew et al. 2015). Males arrive during the first week of May in Wisconsin, Vermont, and Nebraska (Renfrew et al. 2015; DHK, pers. observ.) and during the second week of May in Oregon (Wittenberger 1978). Median first egg dates calculated during this study were 26 May in Nebraska (2010) and Ontario (2013), 5 June in Oregon (2010), and 7 June in British Columbia (2014). Annually, first egg dates vary between 18 and 26 May (median 24 May) in Nebraska (DHK, pers. observ.) compared to 15-25 May in Wisconsin (median 20 May) and 19-25 May in Vermont (median 20 May) (Renfrew et al. 2015).

\section{Bobolink returns and geolocator retention}

We recovered only a small proportion of geolocators primarily due to low return rates. Impacts of geolocators on return rates have been documented for some species (Thaxter et al. 2016, Raybuck et al. 2017), but other studies have found no or mixed effects and more study is needed (López-López 2016, van Wijk et al. 2016). In BC, 2 of 14 birds given geolocators returned, but the reduction in males on the study site (16 to 10) from year 1 to year 2 corresponded closely to the 7 males that received geolocators that did not return. The lengthy migration required to breed in the extreme northwestern edge of the range may bring Bobolinks to their energetic and temporal limits, and carrying a geolocator may exceed energetic budgets or delay arrival (Hupp et al. 2015) to the point where the breeding window is too short to successfully reproduce; as a result, birds may not survive or may truncate their migration. However, a recent meta-analysis found no effect of migration length on the survival of birds wearing geolocators (Brlík et al. 2019). Although we cannot attribute low return rates to geolocators without controls, we recommend only lighter geolocators, developed more recently, be deployed on Bobolink in BC. We observed no deleterious effects of harnesses on Bobolink. Elastic material, now more commonly used, may reduce impacts on birds (Blackburn et al. 2016), although a meta-analysis found its use was associated with reduced survival in passerines (Brlík et al. 2019).

\section{Conclusions}

Migration tactics are ultimately driven by availability of food resources (Newton 2008), and the Bobolink, with its flocking behavior and "split migration" (defined by lengthy stops in the Llanos and often elsewhere) is a prime example (Renfrew et al. 2013). Variability in migration timing represents modifications by proximate factors of endogenous migration timetables. For Bobolink, current food resources modify endogenous schedules that were in part developed in response directly or indirectly to historical food resources (Renfrew et al. 2013), likely driving variability we found in migration timing. We found initial southbound migration timing was more variable for Bobolinks breeding closer to the migration corridor (eastern populations), but other aspects of their migration schedules were not associated with any spatial pattern in breeding location (west to east), suggesting that other factors such as resource availability are more influential. Our findings for Bobolink more closely resemble those for Wood Thrush (stop duration determined winter arrival and other timing) than for Purple Martin, where breeding location was associated with migration schedules. Further miniaturization of geolocator and GPS tracking devices, in addition to cumulative years of research using geolocators, will amass the sample sizes needed for more robust investigations of migration patterns (e.g., Stutchbury et al. 2016a) and associations with breeding and nonbreeding ecology. 


\section{Acknowledgments}

We thank anonymous reviewers for their helpful feedback that improved earlier drafts of this manuscript. We owe many thanks to S Hardy for his valuable field work. The Canadian Wildlife Service/Environment and Climate Change Canada funded field work in Canada. We thank Becky Whittam and Peter Thomas of Environment and Climate Change Canada for their work in New Brunswick. We are forever grateful to the Curtis family for generously opening their home and their hearts year after year.

\section{Literature cited}

Blackburn E, Burgess M, Freeman B, Risely A, Izang A, et al. 2016. An experimental evaluation of the effects of geolocator design and attachment method on betweenyear survival on Whinchats Saxicola rubetra. Journal of Avian Biology 47:530-539.

Brlík V, Koleček J, Burgess M, Hahn S, Humple D, et al. 2019. Weak effects of geolocators on small birds: A meta-analysis controlled for phylogeny and publication bias. Journal of Animal Ecology (January). https://doi. org/10.1111/1365-2656.12962

Calvert AM, Mackenzie SA, Flemming JM, Taylor PD, Walde SJ. 2011. Variation in songbird migratory behavior offers clues about adaptability to environmental change. Oecologia 168:849-861.

Conklin JR, Battley PF, Potter MA, Fox JW. 2010. Breeding latitude drives individual schedules in a trans-hemispheric migrant bird. Nature Communications 1:67.

Cooke WW. 1915. Bird migration. USDA Bulletin Number 185.

Coppack T, Pulido F. 2004. Photoperiodic response and the adaptability of avian life cycles to environmental change. Advances in Ecological Research 35:131-150.

[ESRI] Environmental Systems Research Institute. 2015. ArcMap 10.3.1. Redlands (CA).

Finch T, Saunders P, Aviles JM, Bermejo A, Catry I, et al. 2015. A pan-European, multipopulation assessment of migratory connectivity in a near-threatened migrant bird. Diversity and Distributions 21:1051-1062.

Fraser KC, Stutchbury BJM, Kramer P, Silverio C, Barrow J, et al. 2013. Consistent range-wide pattern in fall migration strategy of Purple Martin (Progne subis), despite different migration routes at the Gulf of Mexico. Auk 130:291-296.

Hamilton WJ. 1962. Bobolink migratory pathways and their experimental analysis under night skies. Auk 79:208233.

Hasselquist D, Montràs-Janer T, Tarka M, Hansson B. 2017. Individual consistency of long-distance migration in a songbird: Significant repeatability of autumn route, stopovers and wintering sites but not in timing of migration. Journal of Avian Biology 48:91-102.

Hupp JW, Kharitonov S, Yamaguchi NM, Ozaki K, Flint PL, et al. 2015. Evidence that dorsally mounted satellite transmitters affect migration chronology of Northern Pintails. Journal of Ornithology 156:977989.
Hurlbert AH, Liang Z. 2012. Spatiotemporal variation in avian migration phenology: Citizen science reveals effects of climate change. PLOS One 7(2):e31662.

López-López P. 2016. Individual-based tracking systems in ornithology: Welcome to the era of big data. Ardeola 63:103-136.

Marra PP, Francis CM, Mulvihill RS, Moore FR. 2005. The influence of climate on the timing and rate of spring bird migration. Oecologia 142:307-315.

McKinnon EA, Fraser KC, Stutchbury BJ. 2013. New discoveries in landbird migration using geolocators, and a flight plan for the future. Auk 130:211-222.

Nathan R, Getzb WM, Revillac E, Holyoak M, Kadmona R, et al. 2008. A movement ecology paradigm for unifying organismal movement research. Proceedings of the National Academy of Sciences 105:1905219059.

Newton I. 2006. Can conditions experienced during migration limit the population levels of birds? Journal of Ornithology 147:146-166.

Newton I. 2008. The migration ecology of birds. London: Academic Press.

Newton I. 2011. Migration within the annual cycle: Species, sex and age differences. Journal of Ornithology 152:169-185.

Nocera JJ, Forbes GJ, Giraldeau L. 2006. Inadvertent social information in breeding site selection of natal dispersing birds. Proceedings of the Royal Society B 273:349355.

Peterson SM, Streby HM, Kramer GR, Lehman JA, Buehler DA, Andersen DE. 2015. Geolocators on Goldenwinged Warblers do not affect migratory ecology. Condor: Ornithological Applications 117:256-261.

R Core Team. 2015. R: A language and environment for statistical computing. Version 3.2.3. Vienna (Austria): R Foundation for Statistical Computing.

Rakhimberdiev E, Saveliev A, Piersma T, Karagicheva J. 2017. FLightR: An R package for reconstructing animal paths from solar geolocation loggers. Methods in Ecology and Evolution 8:1482-1487.

Rakhimberdiev E, Winkler DW, Bridge E, Seavy NE, Sheldon D, et al. 2015. A hidden Markov model for reconstructing animal paths from solar geolocation loggers using templates for light intensity. Movement Ecology 3:25.

Rappole JH, Tipton AR. 1991. New harness design for attachment of radio transmitters to small passerines. Journal of Field Ornithology 62:335-337.

Raybuck DW, Larkin JL, Stoleson SH, Boves TJ. 2017. Mixed effects of geolocators on reproduction and survival of Cerulean Warblers, a canopy-dwelling, long-distance migrant. Condor: Ornithological Applications 119:289-297.

Renfrew RB, Frey SJK, Klavins J. 2011. Phenology and sequence of the complete prealternate molt of Bobolinks in South America. Journal of Field Ornithology 82:101-113.

Renfrew RB, Kim D, Perlut N, Smith J, Fox J, Marra PP. 2013. Phenological matching across hemispheres in a long-distance migratory bird. Diversity and Distributions 19:1008-1019. 
Renfrew R, Strong AM, Perlut NG, Martin SG, Gavin TA. 2015. Bobolink (Dolichonyx oryzivorus). In: Poole A, editor. Birds of North America. Ithaca (NY): Cornell Lab of Ornithology. doi:10.2173/bna.176

Ridgely RS, Allnutt TF, Brooks T, McNicol DK, Mehlman DW, et al. 2003. Digital distribution maps of the birds of the Western Hemisphere, version 1.0. Arlington (VA): NatureServe.

Schmaljohann HJ, Fox JW, Bairlein F. 2012. Phenotypic response to environmental cues, orientation and migration costs in songbirds flying halfway around the world. Animal Behaviour 84:623-640.

Stanley CQ, MacPherson M, Fraser KC, McKinnon EA, Stutchbury BJM. 2012. Repeat tracking of individual songbirds reveals consistent migration timing but flexibility in route. PLOS One 7(7):e40688.

Stanley CQ, McKinnon EA, Fraser KC, MacPherson MP, Casbourn G, et al. 2014. Connectivity of Wood Thrush breeding, wintering, and migration sites based on range-wide tracking. Conservation Biology 29:164 174.

Studds CE, Marra PP. 2011. Rainfall-induced changes in food availability modify the spring departure programme of a migratory bird. Proceedings of the Royal Society B: Biological Sciences 278:3437-3443.

Stutchbury BJM, Fraser KC, Silverio C, Kramer P, Aeppli B, et al. 2016a. Tracking mated pairs in a long-distance migratory songbird: Migration schedules are not synchronized within pairs. Animal Behaviour 114:6368.

Stutchbury BJM, Gow EA, Done T, MacPherson M, Fox JW, Afanasyev V. 2011. Effects of post-breeding moult and energetic condition on timing of songbird migration into the tropics. Proceedings of the Royal Society B: Biological Sciences 278:131-137.

Stutchbury BJM, Siddiqui R, Applegate K, Hvenegaard GT, Mammenga P, et al. 2016b. Ecological causes and consequences of intratropical migration in temperatebreeding migratory birds. American Naturalist 188(S1):S28-S40.

Thaxter CB, Ross-Smith VH, Clark JA, Clark NA, Conway GJ, et al. 2016. Contrasting effects of GPS device and harness attachment on adult survival of Lesser Blackbacked Gulls Larus fuscus and Great Skuas Stercorarius skua. Ibis 158:279-290.

Trierweiler C, Klaassen RHG, Drent RH, Exo K-M, Komdeur J, et al. 2014. Migratory connectivity and population-specific migration routes in a long-distance migratory bird. Proceedings of the Royal Society B: Biological Sciences 281:20132897.

Van Loon A, Ray JD, Savage A, Mejeur J, Moscar L, et al. 2017. Migratory stopover timing is predicted by breeding latitude, not habitat quality, in a long-distance migratory songbird. Journal of Ornithology 158:745752.

van Wijk RE, Souchay G, Jenni-Eiermann S, Bauer S, Schaub M. 2016. No detectable effects of lightweight geolocators on a Palaearctic-African long-distance migrant. Journal of Ornithology 157:255-264.

Vardanis Y, Klaassen RHG, Strandberg R, Alerstam T. 2011. Individuality in bird migration: Routes and timing. Biology Letters 7:502-505.

Wittenberger JF. 1978. The breeding biology of an isolated Bobolink population in Oregon. Condor 80:355-371.

Woodworth BK, Newman AEM, Turbek SP, Dossman BC, Hobson KA, et al. 2016. Differential migration and the link between winter latitude, timing of migration, and breeding in a songbird. Oecologia 181:413-422.

Wotherspoon S, Sumner M, Lisovskis S. 2013. BAStag: Basic data processing for light based geolocation archival tags version 0.3. https://github.com/ SWotherspoon/BAStag 